\title{
コンピュータ分子設計の現状
}

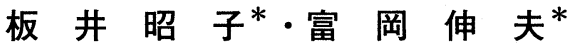

\section{Present Stage of Computer-Assisted Molecular Design.}

\author{
Akiko ItaI $*$ and Nobuo TomiokA *
}

\begin{abstract}
Computer assisted (aided) molecular modeling is becoming a powerful tool for chemists. This trends owes much to increasing computer powers, developments of three-dimensional computer graphics hardwares and developments of computational theory and many good softwares. Among various computational methods, molecular mechanics calculation is popularly used to predict stable structure and/or stable conformation of molecules and to estimate energetics of molecules. Structures of many biologically important small and macro-molecules have been elucidated by X-ray crystallography. Docking simulation study is useful for designing new drugs when the structure of the target protein is known. Along with its merits, current limitations and future of computer assisted molecular modeling are also discussed.
\end{abstract}

\section{1. はじめに}

近年，コンピュータの性能向上と普及は著しく，その 存在を意識するしないにかかわらず, 学術研究, 技術開 発のあらゆる場面でコンピュータの恩恵にあずかれるよ うになった。分子設計の分野でも, コンピュータの名を 冠した手法が注目をあびている。増大する一方の情報を コンピュータによって管理し，論理的な現象解析や分子 設計を指向してコンピュータを利用した巨大数值計算を 行うことが普通になってきた。

一方, 低分子や生体高分子の X 線結晶解析技術の進 歩と，その成果である分子の立体構造の知識の蓄積は目 ざましく, 分子構造に関係する分野のあらゆる研究に原 子レベルの構造的基礎を提供してきた。また, 三次元コ ンピュータ・グラフィックスの進歩は生体高分子を含む 分子の立体構造や分子間相互作用についての理解を助け る役割を果したし、コンピュータとその利用技術の進歩 に支えられた分子力場計算, 分子軌道法計算などの理論 化学計算の日常化は分子の安定性や反応性, 標的生体高 分子との相互作用を説明し，さまざまにシミュレートす るための貴重なツールとなっている。

本稿では対象を主として薬物分子とし，これらの手法 がコンピュータ薬物設計の中で果す役割を説明し, コン

\footnotetext{
*東京大学薬学部

* Faculty of Pharmaceutical Sciences, University of Tokyo
}

ピュータ薬物設計を展開してゆく上での問題点と, 将来 の展望について述べる。

\section{2.コンピュータ分子設計とは}

コンピュータ (支援) 分子設計とは何かと問われる と，定義は極めてあいまいであるが，化合物デー夕を管 理し, 構造を解析し, 安定性や物性を計算し, 構造を比 較し, 構造と活性の関係を調へ，受容体との相互作用を 調へ，活性を予測し，構造を設計するといった目的に， コンピュータを利用する作業がすべて含まれると考えて いい。10 年程前まではコンピュー夕分子 (薬物) 設計 といえば, Hansch-藤田法に代表される定量的構造活性 相関 (Quantitative Structure-Activity Relationships： QSAR）を意味した1)。QSAR はある基本化合物（リー ド) の一連の置換基誘導体について, 構造と活性との関 係を統計的に解析する方法である。分子の分配係数や分 子屈析率, 置換基の疎水定数, 電子効果, 立体効果など さまざまな物性を独立変数とし，活性（1/ $\log \mathrm{C})$ を従属 変数として回帰分析を行う。その後, 最小二乗法計算に より, 各変数に対する係数を求め, 係数の大きさから, それぞれの物性が活性に及ぼす影響の大きさがわかるの で，活性を最適化するにあたり，構造をどう変えていっ たらいいかが推定できる。統計的に意味のある結果を得 るには，ある程度まとまった数の誘導体を合成して活性 を測定しておく必要があるので, 研究がかなり進んでか らでないと，この手法の恩恵にあずかれないという弱点 がある。一連の化合物群の中での統計処理に基づく結果 
しか得られないので，リード・ジェネレーションの目的 には弱いと考えられるが, リード・オプティマイゼーシ ョンの目的には優れている。

一方，近年注目を集めている分子の三次元構造を基礎 にしたコンピュータ分子設計では分子の物性, コンホ メーション, 安定性, 分子間相互作用などを扱うこと で, 構造と活性の関係を説明しょうとする。QSAR では 置換基ごとの物性データがあればいいので，分子の三次 元構造を必要としなかったが, 新しいアプローチでは分 子の立体構造が必須で，すべての出発点である。

このように新しいアプローチが盛んになってきた社会 的理由としては, 従来の方法が一応成熟し限界が見えて きた一方で, 新薬の開発はますます難しくなり, 論理的 な分子設計による開発の効率化とリード・ジェネレーシ ヨンへの期待が強まったことが挙げられる。技術的に は,コンピュータの性能向上と価格低下にともなう急速
な普及が第一に挙げられるが，さらに次のような要因を 挙げることができる。まず，分子の三次元構造を正確に 求める手段として X 線結晶解析に優るものはないが, この解析手法が進歩して, 日常的に行われるようになっ たことと, 結晶学の成果である分子の三次元座標がデー 夕ベース化されて，多くの研究機関で利用できるように なったことが挙げられる。また，分子力場計算や分子軌 道法計算など理論化学計算の方法論の進歩とソフトウェ アの普及，および三次元コンピュータ・グラフィックス 装置の進歩が挙げられる。三次元コンピュータ・グラフ イックスを利用し，分子モデリングから理論化学計算の 機能まで備えた市販分子設計支援ソフトウェアが出現し て，かなり利用されている。研究者がプログラムの開発 に時間や労力をさくことなく, 一定レベル以上のコンピ ュータ化学作業ができるようになり，この分野の底辺を 拡げる役割を果した。以上述べた様々な手法がどのよう

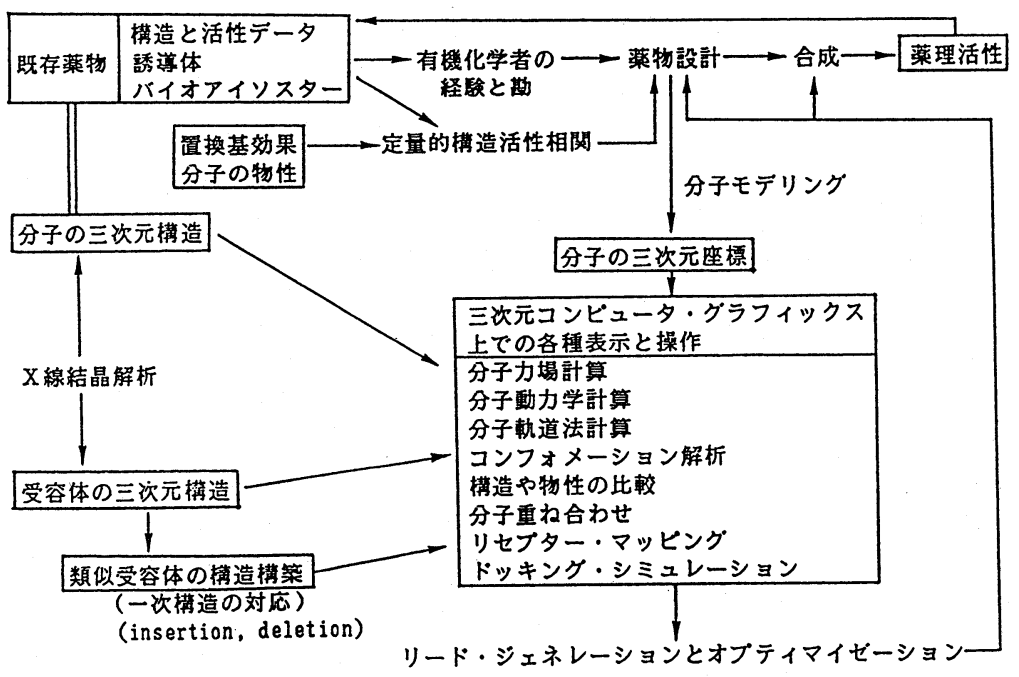

Fig. 1 Drug design : Present and future.

に関わり合っているかを示したのが図 1 である。X 線結 晶解析, コンピュータ・グラフィックス, 理論化学計算 については別の章で詳述する。

現在，コンピュータ支援分子設計作業として一般に行 われているのは, データベース (公共, 自己用) から分 子を検索してその構造を表示する，データベースに必要 な構造がないときは帞算により構造を作る，構造に修正 を加える, 分子力場計算により構造を最適化したポテン シャルエネルギー値を求める, 分子軌道法計算により分 子の物性や反応性や安定性や電荷分布を計算する, いく つかの分子やコンホマーの間で安定性その他を比較す
る，同じ薬理活性を示す分子を（最小二乗法計算なと で）重ね合わせて構造を比較する，酵素などの立体構造 が結晶解析で既知のときは基質や阻害剤分子との分子間 相互作用をドッキング・スタディでシミュレートし，必 要なら分子力場計算でエネルギー最小化する, 活性発現 時のコンホメーションを解析するなどの作業である。こ ういッた作業を通じて何ができるかというと，まず活性 化合物の構造, 物性, とりうるコンホメーションを解析 し，活性を説明し得る仮説をたてる。そして，その仮説 に合った化合物を設計する，あるいはこれから合成しよ うとする化合物が仮説にあてはまるかどうかを予測する 
といったことが可能である。ここで重要なのは信頼でき る活性データと正しい仮説を導くためのロジックと方法 論である。受容体の立体構造が判っていれば, 薬物の結 合の強さとか薬理活性といった現象を説明し, より強い 活性を示す薬物の構造を設計するのもそう困難ではな い。しかし, 薬物受容体といわず, その阻害剤が薬物と して用いられる酵素でさえ, 立体構造が既知のものはそ う多くない。受容体の構造に関する直接の情報なしに, 薬物あるいはそれに対応する生体内活性物質の構造か ら，新しい活性化合物を論理的に設計するのはなかなか 難しい。ある程度構造が rigid な化合物が同一活性を示 すグループに入っていないときは, 分子の重站わせか ら受容体の薬物結合部位の物理的化学的環境を空間的に 表示するリセプタ・マッピングの手法も利用できない。 ペプチドホルモンやプロスタグランジン等の生体内活性 物質は極めてフレキシブルな化学構造をしている。こう いう化合物では構造と活性のデータがきわめて類縁の化 合物からしか得られないことが多い上に, 安定に存在で きるコンホメーションが無数にあるので活性発現時のコ ンホメーションを推定するのが極めて難しい。受容体に 結合したときのコンホメーションは, 単独分子としてエ ネルギー的に安定なコンホメーションと同じであるとは 限らないし, 結晶解析で得られる結晶中の構造とも, NMR 等分光学的に推定される溶液中の構造とも同じで ある必要はない。フレキシブルな分子の活性コンホメー ションの解析は現在のコンピュータ支援分子設計におい て最も難しい問題の一つである。

\section{3. 理論化学計算について}

コンピュータ技術の進歩は自然科学研究に新しい分野 を付け加えた。即ち, 現象を解析し, さらに他のケース

$$
\begin{aligned}
& E_{\text {total }}=E_{\text {bonds }}+E_{\text {angles }}+E_{\text {dihedrals }}+E_{\text {nbd }}+E_{\text {elc }}+E_{H \text {-bond }} \\
& E_{\text {bonds }}=\sum K_{b}\left(r-r_{0}\right)^{2} \\
& E_{\text {angles }}=\sum K_{a}\left(\theta-\theta_{0}\right)^{2} \\
& E_{\text {dihedrals }}=\sum \frac{1}{2} V_{n}\{1+\cos (n \theta-r)\} \\
& E_{v d w}=\sum\left(A_{i j} r_{i j}^{-12}-B_{i j} r_{i j}^{-6}\right) \\
& \text { or } \sum\left\{C_{i j} \exp \left(A_{i j}{ }_{i j}\right)-B_{i j}{ }^{Y} i j^{-6}\right\} \\
& E_{e l c}=K \sum a_{i} a_{j} / \varepsilon \cdot r_{i j} \\
& E_{H \text {-bond }}=\sum\left(-A_{H X}{ }_{i j}^{-10}+B_{H X}{ }_{i j}^{-12}\right) \\
& \mathrm{E}_{\mathrm{vdw}} \text { : Energy for van der Waals interaction } \\
& E_{e l c} \text { : Energy for electrostatic interaction } \\
& \mathrm{E}_{\mathrm{H} \text {-bond }} \text { : Energy for hydrogen bond }
\end{aligned}
$$

Fig. 2 Empirical energy functions used in molecular mechanics calculations.
にあてはめてみることをコンピュータで行う研究であ る。直接観測できない現象を追究する，実験してみれば よいのだが，設定すべき条件が多すぎる，実験に手がか かる，お金がかかる，巨大実験なのでなかなか実験でき ないといったケースで, コンピュータ・シミュレーショ ンが重要になってくる。

コンピュータの質的, 量的発展により, 殆んどどこの 研究機関でも, 理論化学計算が日常的に行われるように なり，今やコンピュータ分子設計を支える大きな柱とな っている。分子設計において有用なのは，分子力場計 算, 分子軌道法計算, 分子動力学計算などであり, 分子 構造の安定性や物性と反応性, 受容体と薬物との相互作 用といった現象を解析して説明し，さらに他のケースで はどうなるかを予測する目的で用いられている。こうし た手法が普及した裏には，これらのプログラム（特に前 二者）がプログラム作成者から提供されて米国にある QCPE (Quantum Chemical Program Exxchange) というシ ステムにより, 殆んど手数料だけの費用で世界中の研究 機関に配布されたという事情がある。

以下, これらの理論化学計算の問題点を述べる。

3.2. 分子力場計算 分子力場計算が非常にルーチン に行われるようになった。実験のかたわら，パソコンで 計算させている人も多い。実験化学者がこうした計算を 気軽にできるようになったのは結構なことであるが，そ の代償として，こうした計算法の問題点や限界を知らず に使う人もあらわれてきた。

分子力場計算とは経験的エネルギー関数とパラメータ を用いて, 分子のポテンシャル・エネルギー值を求め, さらにエネルギーが最小になるように各原子をうごかし て構造を最適化する計算をいう。従って, この計算の結 
果として得られるのは, ある入力された分子構造から出 発して最適化された構造と, そのエネルギー值である。 全エネルギーの中に一般的に含まれているエネルギー項 とその計算式を図 2 に示す。1970 年代に数人の研究者 がそれぞれの作った力場を用いて, 分子力場計算用プロ グラムを作り発表しているが, 現在最もよく用いられて いるのは Allinger らの作った MM2（または MMI）であ る2)。分子力場計算の結果は, そのプログラムが採用し ている力場に依存しており，一般に力場というのは原子 間に働く各種の力の強さとバランスを意味している。力 場は, いろんな実験值（例えば, 振動数, 昇華熱, 生成 熱）に計算值が合うようにエネルギー・パラメータを変 化させていって決定されるので，どういう化合物を用い て，どういう実験值を指標にしたかによって変わってく る。MM2 はstrainのある炭化水素類のジオメトリ（結 合長や結合角), 生成熱等の再現には優れているが, 酸 素, 窒素等へテロ原子を含む分子についてはパラメー夕 が不足していて, 利用上困ることが多い。MM2 は水素 結合のエネルギー項を含まないが，一般的にいってこう した経験的エネルギー計算で水素結合を正しく（精度よ くという意味ではなく，化学的常識に反せずに）扱うこ とは非常に難しいが，生体高分子用に作られた力場計算 プログラム $\left(\mathrm{ECEPP}^{3)}, \mathrm{AMBER}^{4)}, \mathrm{CHARMM}^{5)}\right.$ など）で は水素結合の寄与を無視するわけにいかないので簡略に 取り入れている。分子が共役系を含む場合には一部に簡 略な量子化学的手法をもとり入れたバージョン（MMIPI やMM2P）が出ているし, 電子的な安定性を考慮しつつ 力場計算が行えるものとして Warshel らの QCFF プロ グラム ${ }^{6}$ がある。分子力場計算は想像上の化合物や取り 出すことができないコンホマー，あるいは入手できない 化合物について，その安定性やジオメトリを考慮予測す る目的には非常に有用であるが，この方法で得られたエ ネルギー值自身には物理的意味はなく，あくまでも相対 的な解釈しかできないことを知っているべきである。比 較する分子間で原子数がちがうときも注意を要する。ま た，エネルギー・パラメータが $25^{\circ} \mathrm{C}$ の真空中に孤立し て存在する分子を想定して決められているので, 計算の 結果得られた安定な分子のかたちが溶媒分子や同種分子 に取り囲まれている溶液状態や結晶状態の分子と異なっ ていることも大いにありうる。計算結果が実験の結果と 合わない場合，力場が不完全というか，エネルギー・パ ラメータが未だ十分にリファインされていないために， シミュレーションが正しく行われないという疑いも捨て さることはできない。しかし, 微妙なエネルギー差や構 造のディテールを問題にしないでよい場合もある。例え
ば，分子模型から物差しで読みとったような近似の悪い 座標や分子モデリングでグラフィック画面を見ながら適 当に構築した分子を，一応もっともらしい結合長や結合 角をもち, 内部に異常接近のない構造に修正するのに便 利である。分子軌道法計算プログラムへの入力座標を人 工的に作るときには, そのプログラム内蔵の構造最適化 機能を利用する場合であっても，計算時間を節約し，う っかりミスを減らすために，予じめ分子力場計算を行っ ておくことが役に立つ。

最近は小さい分子だけでなく生体高分子でもこういっ た計算がよく行われている 算プログラムでは，扱う原子数の多さから生ずるコンピ ュータの負荷を少しでも軽くするため, 炭素原子に結合 した水素原子の存在をあからさまには扱わず，その炭素 原子のエネルギー・パラメータの上で考虑するとか, 原 子の座標 $\mathrm{x}, \mathrm{y}, \mathrm{z}$ をエネルギー最小化の変数とせず に，ねじれ角のみを変数とするやり方などがとられてい る。

分子力場計算は核酸の二重ラセン構造でイオンや水分 子を置いたときのシミュレーションや，X線結晶解析さ れた蛋白質の類縁分子（アミノ酸残基が一部置換されて いる, 一次構造上の付加や欠落がある）の立体構造や安 定性をシミュレートするのによく用いられている。ま た，高分子一低分子（高分子）の相互作用をシミュレー トして, 構造と親和性の関係を研究するのにも用いられ る。阻害剤分子との複合体で結晶解析されている酵素で は, 本来の基質分子との結合をシミュレートして, 酵素 反応のメカニズムの解明に使えるし, 他の阻害剂との結 合の様子も推定できて, より親和性の強い薬物としての 阻害剂開発にも役立つ。こうした分子間相互作用のシミ ュレーションは三次元コンピュータ・グラフィックス画 面上で視覚的にシミュレートしてみるドッキング・ス夕 ディと併用すると効率的である。1 分子系においても同 じであるが，こうしたエネルギー最小化計算では，最初 に与えた構造の周辺でしか構造最適化ができないという 問題がある。つまり，フレキシブルな分子でとりうるコ ンホメーションがいくつかある場合，それらすべてを初 期座標として与えてエネルギー最小化をやってみない と, どのコンホマーが真の最安定構造（グローバル・ミ ニマム) なのか判定できない。計算で結合の回転障壁を 越えることは特殊な場合を除いて非常に困難なので，結 合回転の自由度が多い分子では膨大な数のトライアルが 必要になる。これが2 分子系になると, さらに回転と移 動の自由度（2 分子の相対的位置関係の問題）が加わる ので, ローカル・ミニマムの数はぐんと多くなって, も 
はや計算だけではグローバル・ミニマムどころか有望そ うないくつかの安定配置を見つけるだけでも困難にな る。ドッキング・スタディをグラフィック画面上で行う ことにより，重大な見落しをする危険はあっても，人間 の視覚的判断を取り入れざるを得ないゆえんである。

3.2. 分子軌道法計算 分子力場計算が分子のかたち に関する計算だとすれば，分子軌道法計算は分子の性質 に関する計算である。分子のあらゆる性質は，分子の立 体構造によって空間的に保持された原子核とそのまわり に存在する電子の関係によって生ずるが, 量子化学的取 り扱いによってしか電子の挙動についての情報を得るこ とはできない。用いる計算法によっても異なるが，系の 全エネルギー, 軌道ごとのエネルギーと係数, 結合次 数, 電荷分布などが得られ, その值から, イオン化ポテ ンシャル, 双極子能率, 静電ポテンシャルなどの值が計 算できる。特に, コンピュータ分子設計の分野では, 分 子軌道法計算から得られる原子上の形式電荷を, 分子内 エネルギーや分子間相互作用エネルギーの一部である静 電相互作用エネルギーの見積りに用いたり，分子表面上 の静電ポテンシャル值を算出するのに用いることが多 い。このような使用法では，2つの荷電原子間の誘電率 にどういう值を用いるかが, 電荷そのものの精度よりも 大きく影響するが，局所の誘電率を現実的かつ正確に見 積る方法は今のところ確立していない。分子の化学反応 性を論ずるときには, HOMO（最高被占軌道）とLUMO (最低空位軌道) のエネルギー・レベルと軌道のかたち が問題になることもあるし，有機導電性物質など機能性 材料では隣接する分子を含めた電荷分布や電荷移動相互 作用が問題になる。

原子の位置は分子力場計算でもある程度扱えるが，共 役系を含む分子では量子化学的取り扱いが必要である。 最近の分子軌道法計算のプログラムにはどれにも構造最 適化の機能がついていて, 入力した分子構造を系の全工 ネルギーが極小になるように分子構造を最適化してくれ る。

コンピュータのハードウェアおよびこうした計算のた めのソフトウェアの進歩と普及により, 最近は大抵の研 究機関で量子化学計算が手軽にできるようになってき た。とは言っても，扱える分子の大きさは薬物分子レべ ルであり, 蛋白質などの生体高分子については半経験的 方法でも扱えない。薬物-受容体間相互作用の中の静電 相互作用エネルギーを見積る目的には，蛋白質分子中の 原子の電荷としてアミノ酸単位で計算した值を用いるこ とが多い。半経験的方法としては $\mathrm{CNDO}^{10}$, $\mathrm{MINDO}^{111}$, $\mathrm{MNDO}^{12)}$ などの（とくに重なり積分についての）近似法
がよく用いられる。中でも MNDO は近似の程度も適当 で, 普通の薬物分子の大きさの分子に適用できるので最 も繁用されている。しかし, 水素結合や孤立電子対間の 相互作用があるようなケースでの使用は問題があり, 入 力した分子構造での計算では目立たないが, 構造最適化 すると異常が明らかになることが多い。一般に MNDO 法で得られた電荷分布は ab initio 法からのものに比べ, 電荷分布の山と谷が浅くなる傾向がある。

非経験的方法 (ab initio 法) も以前に比してよく用い られるようになってきた。Gaussian 8013)（または82） では入力デー夕も簡単でいろんな basis set が使えるよ うになっていて便利であるが, 対象となる原子数, 軌道 数, 基底関数数など, あらゆるレベルの上限值があっ て, 最小の basis set を用いても薬物分子でそのまま計 算できる大きさのものは少ない。また, 半経験的方法に 比べると格段に計算時間がかかる。 basis set を上げる に従って, さらに計算時間がかかるようになるが, 中程 度の basis setではすべての值の精度が上がるわけでは ないので，目的に応じて使い分けるのがよい。

\section{3. 分子動力学計算 最近, 分子の運動性を問題に} する分子動力学計算という手法が発達してきた。この手 法では, 分子内の全原子に対して, 設定した温度におけ るエネルギー分布に対応する運動エネルギーを与える。 各原子はそのエネルギー值からニュートンの運動方程式 によって導かれる速度をもつことになる。最も速い分子 運動（10-14 秒）よりさらに短い時間間隔で，ときどき 結合長や結合角が異常にならないように修正を加えつ つ, ニュートンの運動方程式に従って, 原子を動かし, ある時間間隔で原子座標を保存してゆく。このシミュ レーションを 10 100 ピコ秒の時間に相当するステップ 数だけおこなう。

エネルギーの評価に経験的エネルギー関数とパラメー 夕を用いる点, 分子力場計算と似ているが, 分子力場計 算との大きな相異点は, 力場計算はある出発座標から工 ネルギー最小化計算を行い，1つの（局所的）安定構造 に達するのが目的であるのに対し, 動力学計算では同じ 構造から出発しても, 原子に熱振動に相当する動きを与 えるために, ある確率でエネルギー障壁を越え, 別の局 所的安定構造に移れることにある。従って，この計算で は，現実にゆれ動く分子の姿を反映して，本質的には終 りがない。(実際にはある時点で打切らねばならない が。）この手法で, 分子運動や位置や形の定まらない溶 媒分子の挙動や分子間相互作用をシミュレートすること がさかんになってきている。代表的なプログラムに $\mathrm{CHARMM}^{5)} \cdot \mathrm{AMBER}^{6)}$ があり，広く用いられている。 


\section{X 線結晶解析}

分子の三次元構造を決定する手段として, 信頼性, 精 度といった点で X 線結晶構造解析に優るものはない。 最近は直接法の進歩, 構造解析用ソフトウェア付きの 4 軸自動回析計の普及もあって, 分子量 1000 以下の分子 の結晶についてはルーチンに行われるようになった。結 晶にならなければいけないという制約があるにしても， 絶対配置, 相対配置, 結合長, 結合角については結晶解 析で得られたものが最も信頼できる。回折計の使用によ り写真法の時代よりも良質の回折強度データが得られる ようになって，3〜8\%の信頼度因子を示す解析がふつう になり, 座標精度も向上した。現在, 普通の解析での推 定標準偏差は結合長について 0.002 0.01̊（水素原子 を含むもので $0.02 \sim 0.08 \AA$ ) , 結合角について $0.1 \sim 2^{\circ}$ (水素原子を含むもので 1 - $4^{\circ}$ ) となっている。もっと も, これらの值はランダム䛊差のみから算出された值で あり，簡単には見積れない実験的な系統誤差を含める と，上記の值の数倍の誤差を含むと考えた方がよいか ら, 細い数值的な比較は注意を要するが，にもかかわら ず，構造的基礎としてはこれ以上確かなものはない。コ ンピュータ分子設計作業で用いる分子モデルとしては充 分な精度をもっているといえる。結合長と結合角につい ては分子力場計算や分子軌道法計算で最適化したものよ りずっと信頼がおけると筆者は考えている。ただし，水 素原子については精度がぐんと下がるので, 幾何学的に 予測される位置に付加し直し，場合によって分子力場計 算により水素原子の位置だけを最適化して用いるのがよ い。回転可能な結合を有する分子のコンホメーションに ついては, 結晶解析で得られたものは結晶中という限定 された条件下で観測されたものであって，NMR など溶 液状態での実験結果と対応しないことも珍しくない。結 晶中で観測された以外のコンホメーションを考慮しなけ ればならないときは，電子的な状態が大きく変わらない 限り, 結晶解析から得られた分子構造から, ねじれ角の みを変化させて異なるコンホメーションを作り出すこと を行う。置換基等の付加, 削除についても, 結晶解析か らの構造をもとにして行うことが多い。学術論文等に発 表された結晶解析からの座標データは, ケンブリッジ結 晶データベースという名でデータベース化され，世界中 で利用されている。文献情報だけで座標データが欠如し ているものもあるが，全部で 4 万を超える化合物の結晶 データが収められ，さらに年々猛烈なスピードで増えつ づけている。

生体高分子の X 線結晶解析については, 1960 年にイ
ギリスの Kendrew がミオグロビンの解析に成功して以 来, 着実に発展をとげてきた。最近は解析手法も確立し たため, 以前に比べて試行錯誤の部分が減り，解析に要 する期間も短縮し，必要な試料の量も少なくて済むよう になってきた。非常に分子量が大きい，多数の分子の複 合体となっている，不安定などの理由で従来は不可能と 信じられてきた難しい解析の成功例がときどき発表され 14.15)，分子生物学に偉大な貢献をなしてきた。こうした 輝かしい成果は, 結晶学自身の進歩もさることながら, 周辺分野の技術の進歩に負うところが大きいように思 う。まず，物質の単離，精製についての生化学的技術の 進歩は著しく，生体中に非常に少量しか存在しないもの や，膜などに存在する複雑な複合体がそのまま取り出さ れて結晶化され，解析されるようになった。また，回折 強度測定関係の技術進歩も目ざましく，シンクロトロン 放射光から出る超強力 $X$ 線の回折結晶学への応用は世 界各地で殆んど日常的に行われるようになってきたし， シンチレーション・カウンターの代りに二次元計数管 (ワイヤ式, $\mathrm{X}$ 線テレビ式，イメージング・プレート式 など）が開発されて，測定スピードが飛躍的にアップし たし, 研究室単位でも持てて強いX 線が使える回転対 陰極型 X 線発生装置も開発されて普及しつつある。こ ういった諸々の進歩のお䔖で, 従来よりもずっと小さな 結晶や，不安定な試料でも測定が可能になった。このよ うに周辺技術の進歩は蛋白結晶学に大きな発展をもたら したが，問題は結晶化である。しかもただ結晶になれば よいのではなく, 結晶の大きさと形, 空間群も問題にな るので, 構造解析に適した結晶を得るのは容易ではな い。にもかかわらず，解析される蛋白質 (酵素) の数は 年々増加しており，ブルックヘヴンで作られている生体 高分子の三次元座標のデータベース（PDB：プロテイ ン・データ・バンク）には約 400 のエントリーが収めら れている。座標データのないものや同じ酵素で分解能や 測定条件の異なるものも入っているので，独立な分子の 構造としてはもっと少ない。論文や学会発表から推定さ れる解析数はかなり多いが, 様々な理由から解析に成功 しても座標データを公開しない傾向が近年強まっている のは憂慮すべきことである。ここ 2,3 年におけるトピ ックスといえば，光合成系蛋白複合体とか ${ }^{16)}$, モノク ローナル抗体と抗原の複合体 ${ }^{17)}$, カゼのウイルスの解析 ${ }^{18)}$ などがある。

ともあれ, 蛋白結晶学の成果は, 生体高分子の立体構 造や分子間相互作用, 分子認識についての理解を深め, 酵素反応メカニズムの原子レベルでの解明に大きな貢献 をなした。遺伝子工学的手法により適切なワンポイン 
ト・ミューテーションをおこした蛋白質をつくることに より, 生体高分子の構造と機能の研究はさらに進むこと が予想されるが19)，人工的な蛋白質は天然のものより結 晶化がむずかしいといわれており, 従って立体構造のレ ベルで解明された成功例は未だ少ない。

薬物設計において標的受容体（あるいは標的となる酵 素）の立体構造を知ることの意義は大きい。ここ数年の 間に, いくつかの薬物受容体（ムスカリン性アセチルコ リン受容体 ${ }^{201}$ とかステロイドホルモン受容体 ${ }^{21}$ など）が 単離され一次構造も決定されているが, 結晶解析は成功 していない。酵素の解析例は多いが，薬物開発に関連し て最も有名な酵素の例が DHFR（ジヒドロ葉酸還元酵 素）である。DHFR は核酸塩基の生合成ルートに含まれ る酵素なので，バクテリアから高等動物にまで広く存在 している。同じ基質に同じ反応を起す酵素でありなが ら，種によってアミノ酸配列が大きく異なり，さらに各 種の阻害剤に対する親和性がまるで異なることがわかっ ている。既に薬物として臨床的に用いられている抗がん 剤メトトレキセート, 抗菌剤トリメトプリム, 抗マラリ ア剂ピリメタミンは DHFR の阻害剤として有名であ り，異なる生物種間での親和性の差を利用している。例 えば，トリメトプリムはE. coli のDHFR に対してはネズ ミ肝の DHFRに比べて，5 万分の 1 の濃度で阻害でき る。こうした親和性の差を説明し，さらに選択性の高い 阻害剂を開発するためには，これらの酵素の結晶解析を 行って，基質結合部位の構造を三次元的に比較してみる 必要がある。実際に DHFR では，乳酸菌，大腸菌，鶏 肝由来のものがいくつかの阻害剤や補酵素 NADPH の存 在下, 非存在下で結晶解析され22.231, その結果が薬物開 発に利用されている 24.25 。将来的には，このような三次 元構造に基づいた論理的なアプローチが少しずつ増えて いくものと思われる。

\section{5. コンピュータ・グラフィックスについて}

機械，建築，電子回路など，あるゆる設計の分野にお いて，コンピュータ・グラフィックスを利用した CAD (Computer Aided Design）の普及は目ざましいものがあ る。グラフィック・ディスプレイに向って，図形や色を デザインし，コンピュータに保存したものを，必要に応 じて呼びだし，修正あるいは条件変更を加えてシミュ レートしてみたり，ボタンを押すだけで清書できるよう になっている。省力化と熟練の不要化といった目に見え るメリットの他に, 情報の保存と取り出しおよびシミュ レーションの容易さが CAD の地位を不動のものにして いる。これらの設計では, 設計の対象と, それから生ず
る機能や結果が予側できる点が, CADD（Computer Aided Drug Design）と異なっている。CADDでは，生 体そのもののメカニズムが解明されていない上に, 薬物 が生体に及ぼす変化が判っていない。薬物が搨取されて から作用を発現するまでの, 吸収, 体内輸送, 膜透過, 代謝といった長い道程の大部分がブラック・ボックスの ままである。さらに設計の直接の対象である化学構造 は, その機能や薬理作用と $1: 1$ に対応しない不利さが あって，薬物設計において CADDは，他の設計分野に おける CADのように決定的な手段となっていない。に もかかわらず，薬物設計においてコンピュータ・グラフ イックスの果す役割は大きく, 今や不可欠な存在となっ ている。特に, 従来からの統計的手法とちがって, 分子 の三次元構造を基礎にしたコンピュータ分子設計におい ては，分子の立体構造や分子間相互作用についての具体 的な理解が不可欠なため，その有用性は大きい。単に分 子の構造が手軽にディスプレイ上で見られる，あるいは プロッターに描けるといったことではなく，コンピュー 夕と繫っていることの利点（膨大な情報保存力と高速な 計算処理能力）とコンピュータ・グラフィックスによる 視覚化が組み合わされた使い方が指向されている。分子 に関するコンピュータ・グラフィックス利用の利点を列 挙してみると, 必要な分子の座標を公共または自己用 データベースから取り出し簡便に表示できる; 現実の分 子模型を組む必要がないので, 手間がかからない, 経済 的，場所をとらない(この利点は高分子では特に大き い）; 再現性や精度がよく，幾何学情報（原子間距離な ど）も簡単に得られる; 1 つの分子について多種の分子 表現や物性表現が可能で容易に切り替えられる;複数の 分子を同一空間において（重ね合わせて），立体構造を 比較できる; 最小二乗法計算等を利用して，複数分子を 一定の共通な方向から比較できる。

三次元コンピュータ・グラフィックスであれば，さら に機能が多く，利点も多い。三次元コンピュータ・グラ フィック・ディスプレイ装置では，グラフィック端末が 三次元座標を保持し，内蔵のハードウェアにより，図形 の回転, 移動, 拡大などの三次元操作が高速に行える。 操作の指示はキーボード入力の他, 付属のタブレット, ダイヤル，ジョイスティックなどの入力装置からアナロ グ的に行えるので，あたかも掌の上の分子模型を扱うよ うに画面上で会話的に分子その他の図形を操作できる。 分子の回転, 移動, 結合回転によるコンホメーション変 化といった分子操作が画面を見ながら高速にできるの で，複数分子の視覚的重ね合わせや分子間相互作用のシ ミュレーションが可能である。特定原子間の距離や分子 
間相互作用エネルギーやコンホメーショナル・エネル ギーなどの数值的指標をリアルタイムに得て, 次の操作 の方向づけの指針とすることができる。さらに分子操作 の結果をそのままホスト・コンピュー夕に保存できるの で, いつでも再現可能だし, 編集して理論化学計算プロ グラムへの入力データとすることも可能である。また， 立体図形の前後を任意の面でクリッピングして断面を表 示することができるので，巨大分子の表面から隠された 部分の様子や，高分子-高分子（あるいは低分子）の相 互作用の様子を原子レベルで把える目的にも優れてい る。必要な部分だけを抽出して拡大したり, 必要な情報 だけを抽出できるなど，コンピュータ・グラフィックス ならではの利点である (口絵参照)。

コンピュータ・グラフィックスで分子図を画くには， 当然のことながら， X 線結晶解析等から得られた三次元 の原子座標が必要であるが，それが手に入らない場合に は，分子モデリングとよばれる作業により想定した分子 の三次元座標を作りあげる。即ち，構造フラグメントや 類似化合物の原子座標からスタートして, 結合の切断や 発生, 原子団の削除や付加, 原子種の変更などの作業を グラフィック画面上で確認しながら会話的に行うと, 能 率もよくミスも少ない。コンホメーションは分子模型で やるときと同様に適当に整え, 必要なら分子力場計算を 行ってエネルギー的に精密化する。

このように, 三次元コンピュータ・グラフィックスを 利用するメリットは主として，ダイナミックな使い方や 会話的な作業にあり, 人間の高度な判断力とコンピュー タとをつなぐインターフェイスとして，重要な役割を果 し得る。いかにコンピュータのハードウェアとソフトウ エアが進歩して，膨大かつ複雑な計算をこなせるように なったとしても, 熟練した化学者が無意識に判断してい る極めて多次元な思考を代行するのは難しいだろう。一 方の化学者のもつ長年の経験に裏打ちされた化学的直感 というのは非常に高度な認識を含んでおり, さらに思考 に巾があって融通がきくのが特徴であるが, 定量性・客 観性・再現性といったものに欠ける。論理的な分子設計 を指向する上でこれらの要素は不可欠である。複雑な現 象を追っている時ほど，人が目で確めながらコンピュー 夕の作業に適切な判断と指示を加えていくやり方が有用 であるように思われる。

最近は三次元コンピュータ・グラフィックスを基本に したコンピュータ分子設計支援システムが国内外で数多 く市販されるようになってきた。各種の分子表示から， 分子モデリング, 分子重㸚わせ, ドッキング・スタデ イができ, さらに各種の理論化学計算機能（分子力場計
算，分子軌道法計算，分子動力学計算など）またはそれ らのプログラムへのインターフェイスを備えているもの が多い。使い勝手など，おしきせになってしまうきらい はあるが, システムによって得意とする方面が違いつつ も, 多くの機能を備えているので, 目的や使用環境を頭 においてそれらの中から選べばたいていの場合事足り る。コンピュータになれていない化学者が使えて, しか も多くの人がいろんな使い方をしても大丈夫という多機 能のシステムを自分でつくるのは，そう簡単ではない。

グラフィックスを含むプログラムは非常にマシーン・ ディペンデントになって扔り，他の機種への移植が大変 である。線を引く, 多角形を塗るといった命令の仕様 (グラフィック基本ルーチン), データの階層構造のとり 方とダイヤルやジョイスティック等入力装置の対応づけ など機種によって全く異なっているためである。三次元 コンピュータ・グラフィックスの画像発生方式には, ベ クター (ランダム・ストローク) 方式とラスター・スキ ヤン方式があって, かつてはベクター方式が圧倒的であ ったのが, 最近ではメモリーが安くふんだんに使えるよ うになったこともあって, 塗りつぶしも可能なラス ター・スキャン型の装置が主流になってきた。ベクター 型にくらべ, 線質は少し落ちるが, 多数のベクトル（線 や点や文字）を書いてもフリッカリング（画面のちらつ き）が扔きない点でも優れている。

\section{6. コンピュータ分子設計の問題点と展望}

機能性分子であれば，分子や分子の集合体の示す物性 や物理化学的性質でその機能が説明できる。しかし, 薬 物分子にあっては，まず作用点に到達でき，さらに作用 点で受容体と強く相互作用できる性質を備えている必要 があるが，薬物分子の生体内に打ける挙動は分子レベル では殆んど解明されておらず，どういう構造だとどうい う挙動を示すかを予測するのは難しい。化学構造上は全 く異なる分子が同じような薬理作用を示すこともある し, 似た化学構造のものが異なる薬理作用を示すことも ある。1つの分子が 1 つの受容体としか相互作用できな いということはないし, バイオアイソステリズム（構造 のことなる化合物がその物理化学的等価性に基づいて,

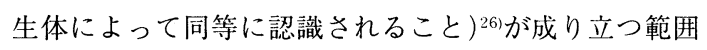
も受容体によって異なると考えられるため, 論理的に一 定の考え方で有効な設計をしていくことは難しい。

また, フレキシブルな構造の薬物や生体活性物質を基 礎にして, 新しい, 出来ればリジッドな構造の薬物を設 計しょうとする場合, 標的受容体に結合したときのコン ホメーションが推定できれば有用である。現在, こうし 
た目的のコンホメーション解析では，系統的にねじれ角 を変化させていって得られるコンホマーの中から，分子 力場計算を行ってエネルギー的に安定なコンホメーショ ンを数ヶ〜数十ヶ選び出して検討の対象とすることが行 われている。このようなアプローチでは, 単独分子とし ての最安定構造から, 何キロカロリ一位不安定な構造ま で考慮すれば，受容体に結合したときの構造が漏れずに すむのかとか, 単独分子としてのローカル・ミニマム (ポテンシャル・エネルギー的に底になった構造で多数 に及ぶことも多い。それらの中で最も安定なものがグ ローバル・ミニマムと呼ばれる) のコンホメーション が，はたして受容体上での安定構造と一致するのであろ うかといった問題がある。

さらにそれに関連して, 薬物一受容体相互作用を論じ るときに, 分子の運動性や柔軟性はどの程度重要なの か，遷移状態を考慮する必要はないのか，なども問題に なる。また，酵素分子の構造が1つの阻害剂分子との複 合体として結晶解析されている場合, その酵素の立体構 造を利用して他の阻害剂分子や基質分子とのドッキン グ・シミュレーションがよく行われるが, induced fit の 現象を考慮しないですむのか，水分子やイオンとの相互 作用やエントロピーの問題をどう扱うかということも問 題である。

このように，コンピュータを利用して論理的に薬物を 設計していこうとするときに問題となる点は多い。これ らの問題はコンピュー夕化学の技術的側面から生じてい ると言うよりもむしろ, 殆んどが生体あるいは受容体側 の未知の部分にかかわって生じていると思われる。今 後, 生体のメカニズムが詳しく解明され, 受容体につい ての立体構造を含めた知識が増し，さらに正当な仮定に 基づいたシミュレーションの成果が蓄積することによっ てしか解決の道はないと思われる。

\section{7. おわりに}

分子の三次元構造を基礎にしたコンピュー夕分子設計 の分野が生れて 10 年ほど経った。この 10 年の進歩は目 ざましく, コンピュータ・グラフィックス, 分子力場計 算, 分子軌道法計算, 分子設計支援システムなどが驚く ほど普及し，便利になった。しかし，現象をうまく説明 している例はあってもコンピュータがエッセンシャルな 役割を果して新薬が設計された例というのはまだ極めて 少ない。現象の説明から一歩進んで, 新しい構造を設計 するための有効な方法論の開発が必要である。しかし， 今のレベルは低くても，今後さまざまなノウハウが蓄積 し，新しい手法が開発されることによって，この分野が
少しずつ成長してゆくことは間違いない。科学技術の進 歩というものが, 常にその時代時代につきまとう不可能 という認識を破って，不可能を可能にしてきた歷史であ ることを考えるとき，コンピュータ分子設計だけを例外 とすることはできない。コンピュータ分子設計の目的は いうまでもなく, リード化合物の創製である。そして, その目的を達成するために何ができそうかというと，現 象の説明や物性の比較を通じて合成化学者の発想を刺激 すること，作用点へ到達するために必要な物性や受容体 への結合を念頭においた論理的設計を可能にすることで あり, 最後にこれは特に難しいと思うが, 目的の活性や 機能を示す可能性の高い化学構造をコンピュータが提示 することが考えられる。

コンピュータはソフトウェアを通じて与えられるロジ ックによってのみ動くものである。そして，その分子設 計に有効なすばらしいロジックが開発されたとしても， 信頼できる構造と活性のデータが多数なければ役に立た ない。生化学的反応経路の解明, 生体高分子の構造と物 性の研究, 薬物の構造と体内動態の解明, 薬物受容体の 単離と立体構造の決定などの研究が今まで以上に重要に なることが予想される。要するに，コンピュータ分子設 計とはいっても考えるのは今まで通り人間の頭脳であ り，合成化学者がいたずらに過大評価も過小評価もする ことなくコンピュータを馬鹿力のある下僕として使いこ なすことを願ってやまない。（昭和62年 9 月21日受理）

\section{文献}

1) C. Hansch, T. Fujita, J. Am. Chem. Soc., 86, 1616 (1964)

2) N. L. Allinger, Adv. Phys. Org. Chem., 13, 1 (1976)

3) F. A. Momany, R. F. McGuire, A. W. Burgess, H. A. Scheraga, J. Phys. Chem., 79, 2361 (1975)

4) P. K. Weiner, P. A. Kollman, J. Comp. Chem., 2, 287 (1981)

5) B. R. Brooks, R. E. Bruccoleri, B. D. Olafson, D. J. States, S. Swaminathan, M. Karplus; ibid., 4, 187, (1983)

6) A. Warshel, Computers \& Chemistry, 1, 195 (1977)

7) M. Levitt, J. Mol. Biol., 170, 723 (1983)

8) R. F. Tilton, Jr., U. C. Singh, S. J. Weiner,M. L. Connolly, I. D. Kuntz, Jr., P. A. Kollman; ibid., 192, 443 (1986)

9) S. J. Weiner, G. L. Seibel, P. A. Kollman, Proc. Natl. Acad. Sci. USA, 83, 649 (1986)

10) J. A. Pople, G. A. Segal, J. Chem. Phys., 44, 3289 (1966)

11) R. C. Bingham, M. J. Dewar, D. H. Lo, J. Am. Chem. Soc., 97, $1285\left(19^{\prime} / b\right)$ 
12) M. J. S. Dewar, W. Thiel, J. Am. Chem. Soc., 99, 4899 (1977)

13) J. S. Binkley, R. A. Whiteside, R. Krishnan, R. Seeger, D. J. DeFrees, H. B. Schlegel, S. Topiol, L. R. Kahn, J. A. Pople, QCPE, 13, 406 (1981)

14) C. Abad-Zapatero, S. S. Abdel-Meguid, J. E. Johnson, A. G. W. Leslie, I. Rayment, M. G. Rossmann, D. Suck, T. Tsukihara, Nature, 286, 33, (1980)

15) T. J. Richmond, J. T. Finch, B. Rushton, D. Rhodes, A. Klug, ibid., 311, 532 (1984)

16) J. Deisenhofer, O. Epp, K. Miki, R. Huber, H. Michel, ibid., 318, 618 (1985)

17) A. G. Amit, R. A. Mariuzza, S. E. V. Phillips, R. J. Poljak, Science, 233, 747 (1986)

18) M. G. Rossman, E. Arnold, J. W. Erickson, E. A. Frankenbreger, J. P. Griffith, H.J. Hecht, J. E. Johnson, G. Kamer, M. Luo, A. G. Mosser, R. R. Rueckert, B. Sherry, G. Vriend, Nature, 317, 145 (1985)

19) K. M. Ulmer, Science, 219, 666 (1983)

20) M. Noda, H. Takahashi, T. Tanabe, M. Toyosato, Y.
Furutani, T. Hirose, M. Asai, S. Inayama, T. Miyata, S. Numa, Nature, 299, 793 (1982)

21) S. Green, P. Walter, V. Kumar, A. Krust, J. M. Bornert, P. Argos, P. Chambon, ibid., 320, 134 (1986)

22 ) D. A. Matthews, R. A. Alden, J. T. Bolin, D. J. Filman, S. T. Freer, R. Hamlin, W. G. J. Hol, R. L. Kisliuk, E. J. Pastore, L. T. Plante, N. Xuong, J. Kraut, J. Biol. Chem., 253, 6946 (1978)

23) D. A. Matthews, J. T. Bolin, J. M. Burridge, D. J. Filman, K. W. Volz, B. T. Kaufman, C. R. Beddell, J. N. Champness, D. K. Stammers, J. Kraut, ibid., 260, 381 (1985)

24) C. Hansch, R. Li, J. M. Blaney, R. Langridge; J. Med. Chem., 25, 777 (1982)

25) L. F. Kuyper, B. Roth, D. P. Baccanari, R. Ferone, C. R. Beddell, J. N. Champness, D. K. Stammers, J. G. Dann, F. E. A. Norrington, D. J. Baker, P. J. Goodford; ibid., 25, 1120 (1982)

26) "Medicinal Chemistry (3rd ed.)", ed. by A. Burger, p. 22, Wiley Interscience (1970)

\section{協会誌バックナンバー在庫表}

下記のバックナンバーが在庫しておりますので，ご希望の方は代金（現金書留）を添えてお申 し込み下さい。

(昭和 62 年 11 月現在)

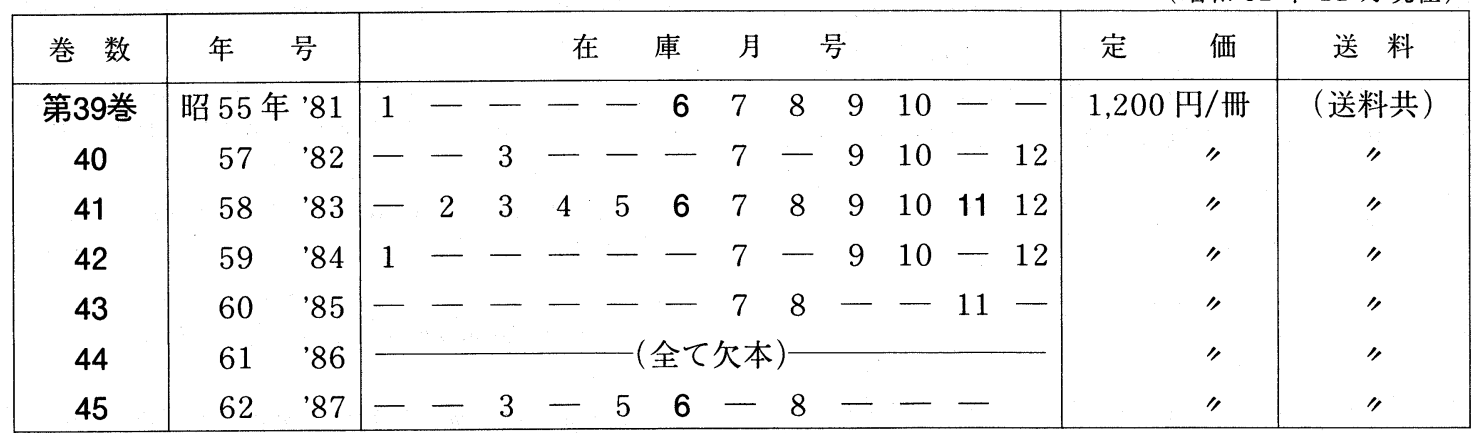

$38-6$ 新製品・新プロセス開発の背景」

|特 $\mid$

$39-6\ulcorner 80$ 年代有機合成化学工業における技術革新」

$41-6\left\ulcorner\mathrm{C}_{1}\right.$ 化学の現状」

11 「生物を利用する有機合成と有用物質の生産」

合えるか」

43-11「有機化学はバイオサイエンスにどこまで関わり

45-6「へテロ原子と機能性物質」

\section{2,000 円/冊（送料共）}

2,500 円/冊 "

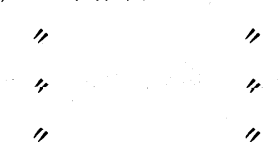

